\title{
Chapter 4 \\ Commentary: A (Mostly) Hydrological Commentary on the Small Retention Programs in the Polish Forests
}

\author{
Martyn Futter
}

From a hydrological perspective, FRM is simple: reduce the height of the flood peak and the flood risk is reduced. In reality, a huge number of biophysical and societal factors complicate the process. The Polish forest small retention program is unique in its manner of addressing these factors. The contribution of Matczak et al. (this volume) is especially welcome as it contributes to the English language literature on practical measures for upstream water retention so as to reduce downstream flood risk. While there are a few publications in English about the Polish programme (e.g., Juszczak et al. 2007; Kowalewski 2008), the voluminous Polish language literature appears to be a treasure trove of useful information for forest managers interested in water retention as well as water managers who are interested in the flood reduction potential of the forest landscape.

There is an apparent contradiction between forest production and flood control. As early as the 1700s, it was argued that site drainage would improve forest productivity (Glacken 1967, p. 488). Measures such as ditching to remove water from poorly drained lands are recognised as among the most cost-effective silvicultural practices for increasing forest yield (Skaggs et al. 2016). Between 1945 and the collapse of the Soviet Union, close to $3 \%$ of the Polish land area was drained, primarily to increase timber production. This led to lower groundwater levels and the loss or degradation of many forest wetlands (Matczak et al. this volume). As the purpose of drainage is to move water off the land, it is likely to increase the height of the flood peak and to exacerbate flooding (e.g., Robinson et al. 2003). So long as forest lands were managed primarily for production, this tradeoff was apparently met with tacit acceptance. In the 1990s, with a reduced focus solely on timber production values, the tradeoffs associated with forest drainage began to be scrutinized more closely (Mårald et al. 2017). For example, new drainage of forest lands in Finland declined substantially in the early 1990s over concerns about biodiversity (Peltomaa 2007).

\footnotetext{
M. Futter $(\varangle)$

Department of Aquatic Sciences and Assessment, Section for Geochemistry and Hydrology, Swedish University of Agricultural Sciences, Uppsala, Sweden e-mail: martyn.futter@slu.se

T. Hartmann et al. (eds.), Nature-Based Flood Risk Management on Private Land, https://doi.org/10.1007/978-3-030-23842-1_4
} 
Matczak et al. (this volume) note that drainage of forest lands in Poland decreased at the same time as national priorities changed with the collapse of the Soviet Union.

Once forest management no longer focused exclusively on timber production, a multifunctional perspective could be adopted and other management goals increased in importance (Farrell et al. 2000). Often, these new goals were related to biodiversity or recreational values, but the importance of water management was also recognised in some locations. With their typically high infiltration capacities and potential for water purification, forests are recognised almost universally as high quality fresh water sources (Neary et al. 2009). By returning moisture to the atmosphere through evapotranspiration, forests are also an important part of the global hydrological cycle (Launiainen et al. 2014). However, the overall link between floods and forests is a matter of ongoing debate (CIFOR 2005). Despite the broader debate about the role of forests in the hydrological cycle, it seems clear from basic hydrological principles that slowing down runoff will flatten out the hydrograph and reduce the height of the flood peak.

The study of Matczak et al. (this volume) raises a number of questions. First of all, to what extent can small retention features enhance the flood risk reduction potential of existing forests? Second, what are the key institutional factors that led to the success of the Polish programme, and are they present throughout Europe? The third question has two parts-what is the optimal arrangement of water retention features in the forest landscape, and how well can human and non-human ecological engineers implement these arrangements?

Using a combination of landscape features and engineering approaches to retain water, as is done in the Polish forest small retention programme, will make a number of contributions to flood reduction. Up to the point at which all available water storage is filled, the downstream flow of water will be slowed and the hydrograph will be flatter than would be expected in the absence of water storage features. It is also likely that water retention features will contribute to increased groundwater recharge, offsetting some of the negative effects of earlier forest drainage. Furthermore, the interception and transpiration of the forest canopy can significantly reduce the fraction of precipitation that eventually contributes to runoff (e.g., Calder 1990).

As noted by Matczak et al. (this volume), small water retention measures are not a panacea for flood risk reduction. The scientific literature is in overwhelming agreement that a certain scale of floods will exceed landscape retention capacity, regardless of the forest management measures employed (e.g., Soulsby et al. 2017). However, increasing evidence suggests that targeted forest management measures can reduce the frequency and/or severity of small floods.

It is likely that one key factor of the success of the Polish small water retention programme is the forest ownership structure. Forests are often owned or managed by the state, which facilitates a landscape-scale approach to water management. Private forest owners are very constrained in their decision-making, and most decisions are made or approved by a state actor (Nichiforel et al. 2018). As a single actor has the ability to make decisions about land management across a large spatial area, ponds and other water retention features can be constructed where they are most appropriate from a hydrological perspective. This might not be possible in countries where forest 
ownership is dominated by a large number of smallholdings, or where forest owners are unwilling to accept loss of future timber revenue associated with the construction of ponds and other water retention features.

The optimal arrangement of water retention features in the landscape is not always apparent. In Poland, the same institutional constraints that would likely exist in countries with forest smallholdings do not apply in the same way. However, the necessary tools for optimal location of retention features may not be fully utilized. Salazar et al. (2012) report a modelling study of pond effectiveness for water retention in a series of catchments across Europe. Matczak et al. (this volume) note that similar studies have been conducted in Poland, but it seems that other modelling tools could give more useful results than the ones they present. Specifically, GIS models based on high resolution LiDAR data have a great deal of potential for identifying candidate water retention sites (Collentine and Futter 2018). Much, if not all, of Poland is now covered by a suitable LiDAR data set, and this could be exploited more effectively.

One open question is the role of beavers in the Polish forest landscape. Matczak et al. (this volume) allude briefly to this issue, but it may be more prominent in the future (e.g., Gorczyca et al. 2018). Beavers are ecological engineers that build dams to create flooded habitat. Beaver ponds can function in a different ecological and hydrochemical manner than small artificial ponds (Ecke et al. 2017). These differences should be explored further as beavers continue to recolonize the Polish forest.

We can learn a number of lessons from this case study in particular and the Polish forest small water retention program in general. Perhaps the most important of these is that multifunctional forestry can work. Forest harvest, expressed as roundwood removal rates, has continued to increase (Eurostat, "roundwood removals by type and assortment") at the same time as pond construction and forest water retention capacity have increased. Equally important to the success of the Polish programme are the institutional and governance structures that facilitate the adoption and construction of water retention features. This may not be possible in jurisdictions dominated by forest smallholdings or where the capacity for top-down decision-making is limited. Two further lessons may not be as important but equally relevant to the question of flood risk reduction measures on private land. The first has to do with the incomplete uptake of the available technology. Models are available for quantifying landscapescale water retention capacity, and new data, specifically high-resolution LiDAR surveys can support these initiatives. The second is how to better integrate human and non-human ecological engineers in production landscapes. Beavers are perceived as damaging to the forest economy but can be an important contributor to forest multifunctionality as their dams and ponds increase water holding capacity and can act as biodiversity hotspots.

The overarching message for my discipline and my colleagues is to learn from the Polish experience. The small water retention programme works, and, with appropriate adaptation, it could be implemented elsewhere in Europe. 
Acknowledgements Open access of this chapter is funded by COST Action No. CA16209 Natural flood retention on private land, LAND4FLOOD (www.land4flood.eu), supported by COST (European Cooperation in Science and Technology).

\section{References}

Calder IR (1990) Evaporation in the uplands. Wiley

CIFOR (2005) Forests and floods: drowning in fiction or thriving on facts? Forest Perspectives 2, RAR Publication 2005-3

Collentine D, Futter MN (2018) Realising the potential of natural water retention measures in catchment flood management: trade-offs and matching interests. J Flood Risk Manag 11(1):76-84

Ecke F, Levanoni O, Audet J, Carlson P, Eklöf K, Hartman G, McKie B, Ledesma J, Segersten J, Truchy A, Futter M (2017) Meta-analysis of environmental effects of beaver in relation to artificial dams. Environ Res Lett 12(11):113002

Farrell EP, Führer E, Ryan D, Andersson F, Hüttl R, Piussi P (2000) European forest ecosystems: building the future on the legacy of the past. For Ecol Manag 132(1):5-20

Glacken CJ (1967) Traces on the Rhodian Shore: nature and culture in Western thought from ancient times to the end of the eighteenth century, vol 170. University of California Press

Gorczyca E, Krzemień K, Sobucki M, Jarzyna K (2018) Can beaver impact promote river renaturalization? The example of the Raba River, southern Poland. Sci Total Environ 615:1048-1060

Juszczak R, Kędziora A, Olejnik J (2007) Assessment of water retention capacity of small ponds in Wyskoć agricultural-forest catchment in western Poland. Pol J Environ Stud 16(5)

Kowalewski Z (2008) Actions for small water retention undertaken in Poland. J Water Land Dev 12:155-167

Launiainen S, Futter MN, Ellison D, Clarke N, Finér L, Högbom L, Laurén A, Ring E (2014) Is the water footprint an appropriate tool for forestry and forest products: the fennoscandian case. Ambio 43(2):244-256

Mårald E, Sandstrom C, Nordin A (2017) Forest governance and management across time: developing a new forest social contract. Routledge, Abington

Neary DG, Ice GG, Jackson CR (2009) Linkages between forest soils and water quality and quantity. For Ecol Manage 258(10):2269-2281

Nichiforel L, Keary K, Deuffic P, Weiss G, Thorsen BJ, Winkel G, Avdibegović M, Dobšinská Z, Feliciano D, Gatto P, Mifsud EG (2018) How private are Europe's private forests? A comparative property rights analysis. Land Use Policy 76:535-552

Peltomaa R (2007) Drainage of forests in Finland. Irrig Drain: J Int Comm Irrig Drain 56(1):151-159

Robinson M, Cognard-Plancq AL, Cosandey C, David J, Durand P, Führer HW, Hall R, Hendriques MO, Marc V, McCarthy R, McDonnell M (2003) Studies of the impact of forests on peak flows and baseflows: a European perspective. For Ecol Manage 186(1-3):85-97

Salazar S, Francés F, Komma J, Blume T, Francke T, Bronstert A, Blöschl G (2012) A comparative analysis of the effectiveness of flood management measures based on the concept of" retaining water in the landscape" in different European hydro-climatic regions. Nat Hazards Earth Syst Sci 12(11):3287-3306

Skaggs RW, Tian S, Chescheir GM, Amatya DM, Youssef MA (2016) Forest drainage. In: Amatya DM, Williams TM, Bren L, de Jong C (eds) Forest hydrology: processes, management and assessment. CABI, pp 124-140

Soulsby C, Dick J, Scheliga B, Tetzlaff D (2017) Taming the flood-how far can we go with trees? Hydrol Process 31(17):3122-3126 
Martyn Futter is a hydrologist with a strong interest in quantitative hydrology and the social dimensions of water. He has worked extensively with forest water issues in Sweden and has developed a rainfall runoff model that has found use in North America, Europe, Asia and Africa.

Open Access This chapter is licensed under the terms of the Creative Commons Attribution 4.0 International License (http://creativecommons.org/licenses/by/4.0/), which permits use, sharing, adaptation, distribution and reproduction in any medium or format, as long as you give appropriate credit to the original author(s) and the source, provide a link to the Creative Commons license and indicate if changes were made.

The images or other third party material in this chapter are included in the chapter's Creative Commons license, unless indicated otherwise in a credit line to the material. If material is not included in the chapter's Creative Commons license and your intended use is not permitted by statutory regulation or exceeds the permitted use, you will need to obtain permission directly from the copyright holder.

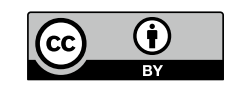

